\title{
Lost and unfulfilled relationships behind emotional loneliness in old age
}

\author{
ELISA TIILIKAINEN* and MARJAANA SEPPÄNEN $\dagger$
}

\begin{abstract}
Using a qualitative approach, this article examines how the experiences of emotional loneliness are embedded in the everyday lives and relationships of older adults. Ten in-depth interviews were conducted in 2010 with older people who reported feeling lonely, often or all the time, during a cohort study in southern Finland. The research reveals the multifaceted nature of loneliness and its causes. Behind emotional loneliness, we identified lost and unfulfilled relationships, involving the loss or lack of a partner, the absence of a meaningful friendship, complex parenthood and troubling childhood experiences. Most of the interviewees have faced loneliness that only began in old age, but for some, loneliness has been present for nearly a lifetime.
\end{abstract}

KEY WORDS-loneliness, emotional loneliness, ageing, relationships, qualitative, interview, lifecourse.

\section{Introduction}

During the course of our lives we form, maintain and rebuild relationships with family, friends, neighbours and acquaintances, with some relationships ending up more meaningful than others. Meaningful relationships are regarded as the basis of a good and dignified life, and the lack of them as a risk for loneliness (Gunnarsson 2009; Savikko 2008; Victor, Scambler and Bond 2009).

Loneliness is often associated with old age; not in the sense of ageing, per $s e$, but with the increase of disability and the decrease of social integration that may follow (Jylhä 2004; Savikko et al. 2005; Victor, Scambler and Bond 20o9; Wenger et al. 1996). Loneliness is known to manifest with depression (Cacioppo, Hawkley and Thisted 2010; Jylhä and Saarenheimo 2010), increased mortality (Luo et al. 2012; Victor and Bowling 2012), the use of hospital emergency departments (Geller et al. 1999; Molloy

* Department of Social Sciences, University of Eastern Finland, Kuopio, Finland.

$\uparrow$ Department of Social Research, University of Helsinki, Finland. 
et al. 2010) and the likelihood of nursing home admission (Russell et al. $1997)$.

Even though loneliness of older adults has become a broadly discussed societal topic in Finland (Uotila, Lumme-Sandt and Saarenheimo 2010), as well as in other European countries (Victor, Scambler and Bond 2009), the majority of studies show that the proportion of people experiencing severe loneliness has remained about the same or even decreased during the past decades (Victor and Bowling 2012; Victor et al. 2005). Studies have reported that up to one-third of older people experience some degree of loneliness in later life (Savikko et al. 2005; Steed et al. 2007; Victor et al. 2005; Wenger and Burholt 2004). Loneliness is a severe problem for $3^{-9}$ per cent (Victor and Bowling 2012).

Results from cross-sectional studies have suggested that loneliness is most common among the very old (Fees, Martin and Poon 1999; Holmén et al. 1992; Routasalo et al. 2006). However, according to Yang and Victor (2011), loneliness demonstrates a non-linear U-shaped distribution, with those aged under 25 years and those aged over 65 years demonstrating the highest levels of loneliness (see also Andersson 1998).

Despite substantial research concerning the topic, loneliness lacks a clear consensual definition. The concepts of feeling lonely, being alone and living alone are often used interchangeably (Graneheim and Lundman 2010; Victor, Scambler and Bond 2009). Rokach (2004: 25) defines loneliness as a universal phenomenon, common to all of us, 'but the nature of loneliness as a subjective experience is varied across different people, under many conditions, with a multitude of causes and enumerable results and consequences'.

Loneliness is widely understood as a multidimensional and subjective phenomenon (Cacioppo and Patrick 2008; Jong Gierveld 1998; Marangoni and Ickes 1989; Victor, Scambler and Bond 2009). Different pathways to loneliness have been identified; it may be a continuation of a long-established attribute, or it can also decrease during the course of one's life. Loneliness can be a new experience, caused by 'triggers' occurring in later life, e.g. losing a partner (Aartsen and Jylhä 2011 ; Victor et al. 2005). Longitudinal studies have identified groups of older people for whom loneliness decreases, as well as those for whom loneliness increases and for whom loneliness has been an enduring experience (Victor and Bowling 2012; Victor, Scambler and Bond 2009).

According to Jylhä and Saarenheimo, loneliness is best understood as a relational concept:

First, the individual experience of loneliness requires, at minimum, an awareness of what it means to have meaningful relationships or contact with others, or to be a part 
of a community. Secondly, most theoretical models of loneliness rely on comparisons, where a current state of being is set against a person's past or anticipated future situation or the situation of others. (2010:317)

Likewise Dahlberg (2010) has highlighted that loneliness experienced 'now' includes also earlier experiences as well as those that are expected in the future.

Even though the subjective nature of the phenomenon is recognised, research concerning loneliness in old age has been focused on its prevalence and predictive factors, and there has been only a small number of qualitative studies on the topic (Dahlberg 2010; Graneheim and Lundman 2010; Heravi-Karimooi et al. 2010; Kirkevold et al. 2013; McInnis and White 2001; Stanley et al. 2010; Uotila 2011; Victor, Scambler and Bond 2oog). These studies have highlighted the different but interrelated dimensions and the temporal and changing nature of loneliness (Stanley et al. 2010) plus its negative influence on the everyday lives of older people (Heravi-Karimooi et al. 2010). McInnis and White (2001) interpreted loneliness as a fracture of important relationships; a state of anxiety, fear and sadness, and a state of silent suffering.

Victor, Scambler and Bond (2009) describe a link between loneliness and very close loss, which they separated into two categories dependent on whether the loss directly or indirectly has an effect on the person's level of social interaction. Loss of a partner, confidante, child or best friend were described as losses, with direct reduction of social interaction. Loss of health, mobility, financial independence, transport and paid employment, and change in the nature of the external environment or neighbourhood, were described as losses indirectly affecting ones propensity to loneliness.

Uotila (2011) found that older people explained their loneliness as a result of diminishing social relationships and weakening physical ability. Also, negative attitudes towards older people as well as changes in identity and behaviour with age were interpreted as the causes of loneliness. Dahlberg (2010) makes a distinction between loneliness felt because of being on one's own and loneliness felt alongside others. For the latter type, Dahlberg (2010) describes it as loneliness being felt when living with a partner, and loneliness felt by persons needing care. She describes the feelings of loneliness not only as strange, wrong, ugly or even shameful, but also restful and peaceful.

Granheim and Lundman (2010) point out that loneliness among the very old can be either devastating or enriching, depending on their life circumstances and outlook on life and death. Similar findings have been made by Kirkevold et al. (2013), who emphasise the importance of identifying older people who struggle with accumulating losses, and developing more individualised interventions to alleviate loneliness. 
Loneliness studies have frequently referred to Robert Weiss' (1973) conceptualisation of social and emotional dimensions of loneliness: emotional isolation refers to the absence of a significant other or someone to turn to, and social isolation relates to loneliness caused by a lack of a sense of belonging or dissatisfaction towards one's social network. According to Weiss, the absence of a close emotional attachment can be remedied only by the integration of another emotional attachment or the reintegration of the one that had been lost; and the absence of an engaging social network can be remedied only by access to such a network.

Despite the influence of Weiss' (1973) conceptualisation, relatively little research concerning older people has examined emotional and social loneliness separately (Dahlberg and McKee 2013). According to Baarsen et al. (2001), the distinction between emotional and social loneliness may be particularly relevant for studies among older people, because ageing relatives and friends die so the probability of having or finding an intimate attachment figure decreases with age.

Dahlberg and McKee (2013) point out the importance of examining social and emotional loneliness separately in order to prevent or reduce loneliness; understanding the different natures of loneliness is needed before effective intervention policies and strategies can be developed. Liu and Rook (2013) argue that understanding the relationship experiences that underlie the two kinds of loneliness will benefit from attention to negative as well as positive social exchange.

Quantitative studies that have distinguished emotional and social loneliness have found that being female, the absence of a partner, being widowed, being a care-giver, having limited contact with children and relatives, low self-esteem and low income are more highly correlated to emotional than social loneliness (Drennan et al. 2008; Dykstra and Fokkema 2007; Dykstra and Jong Gierveld 2004). However, little is known about the lived experiences behind the two emotional or social - forms of loneliness (Dahlberg and McKee 2013).

\section{Aim and methods}

Stereotypically, an older person experiencing loneliness is seen as someone living alone, hoping for someone - anyone - to come by (see Victor, Scambler and Bond 2009). In this article, we focus on emotional loneliness in order to grasp the experiences of loneliness associated with the absence of a specific attachment figure rather than lack of social integration, which has been more often associated with social loneliness (e.g. Baarsen et al. 2001). This adds to the understanding of how emotional loneliness develops within older people. 
Using a qualitative approach, we examine emotional loneliness as a lived experience that exists in the form of multiple realities constructed and reconstructed by older people within the context of their different lives and life histories (Victor, Scambler and Bond 2009). Our purpose is not to establish factually accurate historical record of the lives of our interviewees, but rather to grasp the lived experiences behind loneliness and what they have meant to the people experiencing them. We ask how emotional loneliness occurs and how the experiences of emotional loneliness are embedded in the past or present everyday lives and relationships of older adults.

Our article has its origins in the quantitative study, 'Good Ageing in Lahti Region' (GOAL), carried out in Päijät-Häme, a hospital district of 15 municipalities located in southern Finland. In the GOAL study, three birth cohorts (1946-1950, 1936-1940 and 1926-1930) had been followed in 2002, 2005, 2008 and 2012. The baseline assessment of the cohort study included two extensive questionnaires and clinical measures. On the topic of loneliness, the respondents were asked a single question, 'Do you feel lonely?', with five alternative answers: 'never', 'seldom', 'occasionally', 'often' and 'all the time'. In 20o8, only a handful $(3 \%)$ of the two oldest cohorts reported being lonely often or all the time $\left(N=13_{11}\right)$. Among the respondents who reported being lonely, those who had given their address information $(\mathrm{N}=39)$ were contacted by mail and invited to an interview to discuss the topic of loneliness further. Ten of them responded.

Table 1 reports the basic information of the interviewees. Four of them are women and six were men. At the time of the interviews they were $7 \mathrm{O}^{-}$ 84 years old, with different backgrounds: widowed, divorced, unmarried or living with a partner; and they lived in different types of neighbourhoods: countryside, centre of the city or suburbia (Table 1). The names of the interviewees have been changed, and other information that could lead to their identification has been removed. The research has received ethical clearance from the ethics committee of the hospital district of Päijät-Häme.

In this article, we analyse the qualitative data gathered between the last two follow-ups of GOAL. The data consist of ten in-depth interviews conducted in 2010. All of the interviewees reported feeling lonely often or all the time in the questionnaire that they answered in 2008. Two of them (Aatos and Helmi) answered feeling loneliness 'all the time'. The rest responded feeling 'often' lonely (Table 1 ). Eight of the interviews occurred at the older people's homes; however, two men were interviewed at an office space, upon their request. The interviews lasted from one to three hours, and they were all recorded. The recorded material was transcribed fully into approximately 200 written pages. 


\section{T A B LE 1. Basic information about the interviewees}

\begin{tabular}{|c|c|}
\hline $\begin{array}{l}\text { Name and age } \\
\text { (years) }\end{array}$ & Other basic information \\
\hline Aatos, $8_{3}$ & $\begin{array}{l}\text { Male, divorced, lives alone in a rural settlement, one child; lonely all the } \\
\text { time }\end{array}$ \\
\hline Anja, 82 & Female, widowed, lives alone in the countryside, one child; often lonely \\
\hline Anneli, 72 & Female, never married, lives alone in suburbia, no children; often lonely \\
\hline Eini, 81 & Female, widowed, lives alone in suburbia, two children; often lonely \\
\hline Helmi, 73 & Female, divorced, lives alone in suburbia, one child; lonely all the time \\
\hline Heikki, $8_{3}$ & Male, widowed, lives alone in the countryside, no children; often lonely \\
\hline Lauri, 81 & Male, divorced, lives alone in a city centre, no children; often lonely \\
\hline Olavi, 80 & Male, married, lives alone in suburbia, two children; often lonely \\
\hline Pauli, 70 & $\begin{array}{l}\text { Male, divorced, currently in a relationship, lives with his partner in sub- } \\
\text { urbia, three children; often lonely }\end{array}$ \\
\hline Vilho, 81 & Male, widowed, lives alone in a rural settlement, two children; often lonely \\
\hline
\end{tabular}

The analysis process was based on Derek Layder's (1998) model of adaptive theory, which can be described as a process between theory testing and theory building. Within adaptive theory, the analysis can be made as datadriven, but the codes and themes are not generated ex nihilo, but with more or less systematic prior theoretical ideas (Layder 1998).

At the first stage of the analysis, we read through the data several times and pre-coded it in order to investigate the possibilities and potentialities of the data. After this, we began giving names, core codes, such as widowhood, unfulfilled expectations, loss of hearing and grand childlessness, to the main points revealing reasons and experiences behind loneliness. With Weiss' (1973) conceptualisation in mind, we started reading the core coded data again and labelling the codes with either emotional loneliness or social loneliness. At this point, the analysis brought up five factors behind emotional loneliness (loss of spouse, lack of companion, longing for a good friend, complex parenthood and troubling childhood experiences) and five factors behind social loneliness (loss of mobility, increased disabilities, individualisation, re-location and decrease of social network). After this, the factors were analysed within three themes: life events, impacts on everyday life and emotional experiences in order to gain understanding of loneliness as a lived experience. In this article, we focus on emotional loneliness, which we describe as lost and unfulfilled relationships.

Table 2 summarises the four themes identified behind emotional loneliness: (a) the loss or lack of a partner; (b) the absence of meaningful friendship; (c) complex parenthood; and (d) troubling childhood experiences. The life events, everyday life impacts and the emotional experiences behind these lost and unfulfilled relationships are also described in order to add to the understanding of how the experience of loneliness is 
T А B L E 2. Lost and unfulfilled relationships behind emotional loneliness in old age

\begin{tabular}{|c|c|c|c|c|}
\hline & Loss or lack of a partner & Absence of meaningful friendship & Complex parenthood & $\begin{array}{l}\text { Troubling childhood } \\
\text { experiences }\end{array}$ \\
\hline Life events & $\begin{array}{l}\text { - Widowhood } \\
\text { - Divorce } \\
\text { - Singlehood }\end{array}$ & $\begin{array}{l}\text { - Loss of a friend } \\
\text { - Changes in friendship due to chan- } \\
\text { ging circumstances (e.g. moving to a } \\
\text { different neighbourhood or friend } \\
\text { finding a partner) } \\
\text { - Lifelong difficulties in finding } \\
\text { meaningful friendship }\end{array}$ & $\begin{array}{l}\text { - Loss of one's child } \\
\text { - Trouble with own children } \\
\text { - No children or grandchildren }\end{array}$ & $\begin{array}{l}\text { - Loss of one's mother } \\
\text { - Mother's depression } \\
\text { - Wartime experiences }\end{array}$ \\
\hline $\begin{array}{l}\text { Impacts on } \\
\text { everyday life }\end{array}$ & $\begin{array}{l}\text { - Loss of sharing and doing } \\
\text { activities together } \\
\text { - No one to take care of } \\
\text { - No one to share affection } \\
\text { with } \\
\text { - No one to share joys and } \\
\text { - Porrows with } \\
\text { - Painful memories }\end{array}$ & $\begin{array}{l}\text { - Unfulfilled expectations } \\
\text { - No one to share joys and sorrows } \\
\text { with } \\
\text { - No one to spend time with }\end{array}$ & $\begin{array}{l}\text { - Unfulfilled expectations } \\
\text { - Lack of emotional support }\end{array}$ & $\begin{array}{l}\text { - Struggling with identity } \\
\text { - Painful memories }\end{array}$ \\
\hline $\begin{array}{l}\text { Emotional } \\
\text { experiences }\end{array}$ & $\begin{array}{l}\text { - Grief } \\
\text { - Feeling of uselessness } \\
\text { - Longing for affection }\end{array}$ & $\begin{array}{l}\text { - Disappointment } \\
\text { - Lack of 'same wavelength' }\end{array}$ & $\begin{array}{l}\text { - Feeling of uselessness } \\
\text { - Disappointment } \\
\text { - Lack of continuity in chain of } \\
\text { generations }\end{array}$ & $\begin{array}{l}\text { - Grief } \\
\text { - Rootlessness } \\
\text { - Fear of being alone } \\
\text { - Insecurity }\end{array}$ \\
\hline
\end{tabular}


constructed within the context of people's lived experiences ( see also Victor, Scambler and Bond 2009). In the results section we provide a deeper insight into the different experiences behind loneliness as described by the interviewees. For many the cause of loneliness was ambiguous; it was an outcome of different factors intertwined together.

\section{Results}

\section{Loss or lack of a partner}

Several research findings have emphasised the link between widowhood and loneliness (Berg et al. 1981; Jylhä 2004; Kivett 1979; Routasalo et al. 20o6; Samuelsson, Andersson and Hagberg 1998; Tijhuis et al. 1999; Victor et al. 2005). Anja lost her husband a few years before the interview. Now she lives alone in the countryside in a big house built by her husband. Memories of the couple's life together are present every day.

During the 61 years together, you get used to the person next to you. You know his ways so well. And he was a kind man. Never lost his temper or went on about little things. Such a special character. Now I see it. I took it for granted, and now I miss him so much. Just two old people living happily together. That I really miss. (Anja)

Anja talks about their everyday life. She misses the way they did everything together in their own particular way (see also Lopata 1969). After her husband passed away, Anja sometimes found she was talking to herself. In her mind, she was sitting at the table, eating breakfast across from her husband, just like old times. Nights went by with her crying and screaming. Anja felt sad, angry and guilty.

Anja's husband passed away suddenly, and she felt unprepared for the loss. Years before, Anja had prayed that she would not have to be the one left alone; she was not the stronger one, she thought. Although she had become used to living alone, she misses her husband's presence every day. Anja says that seeing friends makes loneliness go away, but only for a while: at the end of the day, there is an empty house waiting, with all of the memories in it. Anja says that loneliness was a stranger in her past life, but now it is present every day.

Heikki also lost his partner a few years before the interview. Heikki's wife suffered from Alzheimer's disease and was in a nursing home for nearly ten years. Before that, Heikki had taken care of her at home. The years as a caregiver were difficult and wearing on him, and it was a great relief when a place was obtained for her at the nursing home. But even then, Heikki did not give up his role as a care-giver; he visited her every day.

Heikki had always hoped that he could take care of his wife until the end, and he felt that he succeeded in the task, which he describes as the most 
important one in his life. Similar to Anja, Heikki also lives in the countryside in the same house where he lived with his wife. The adaptation to the loss had begun years before, when they had found out about his wife's disease. After she passed away, life became meaningless, and Heikki started to wonder whether there was still a place for him in the world. For years he had someone to take care of and suddenly it was all gone.

After she died and everything was taken care of, I felt so useless. I told everyone I was ready to go. (Heikki)

For both Heikki and Anja, widowhood has meant not only emotional loneliness but also social isolation, being alone in a house they used to share with a loved one. Their loneliness is based on longing for something lost; for the life they used to have. For Eini, loneliness reminds her of what life could have been:

Maybe if he had lived another 10 or 12 years, I would be different now. We had just started a new life together. The boys were away but visited a lot. Every Christmas we spent here together. Life had meaning. Now there's nothing. (Eini)

Eini lost her husband 15 years ago, just a few years after they had both retired. Life felt good; they both seemed healthy and were renovating their summer cottage together. Eini's husband passed away soon after a cancer diagnosis. Since his death, Eini has stayed at the apartment where they moved together 30 years ago. The building has no elevator, and she lives on the second floor. Over the past years, Eini's declining health has restricted her mobility, and at the same time, several of her friends have passed away. She has help from her two sons, but the quality of her everyday life at home has decreased. Eini is struggling to get by on her own, and the cause of loneliness seems clear for her. 'Your life companion should be there for you longer', Eini says. For an older adult living alone maintaining, let alone building new relationships, can be extremely challenging due to the decrease of physical function (Drageset 2004; Victor et al. 2005).

Divorced and widowed men, more than women, are known to adapt more easily to the loss of a partner and to benefit from a new relationship. Finding a new companion is especially in the interest of men who miss the care and attention of a spouse, which might have been taken for granted before (Jong Gierveld 2004). This can be understood also from Lauri's experience with loneliness.

Lauri lives alone in a block of apartments in the city centre. He is single, having been divorced in the 1970 os. Since then, he has had several relationships, but for the past few years, he has been without a partner. Lauri says that he just has not found the right person. Loneliness comes to mind especially in the evenings. 
Lauri: Days go by okay, but in the evenings, I miss company.

Elisa: Whose company do you miss the most? A lady friend?

Lauri: Well, of course, a lady friend. They're harder to find. (laughs)

A bit amused, he continues to relate that he feels lonely not only in the evening, but also when chores have to be done and bills have to be paid. Lauri says that he was not lonely when he was younger, even though nothing much has really changed since then. Lady friends have come and gone, but 'Now when you're older, you have the time to think about it, and you realise that you're lonely', he admits. If the right person comes along, Lauri might even get married again someday.

Drennan et al. (2008) have found that among those who have never been married or are divorced, the experience of emotional loneliness or lack of 'romantic' companionship is common. Among the widowed interviewees, only Eini brought up the topic of a new partner but from a different point of view than that of Lauri, who is seeking a new spouse.

I haven't been interested in other men. After my brother died, his wife went on about her adventures with other men and kept asking me why I don't find someone too. I always said I'm not interested in men anymore. I'm interested in good friends among other women. (Eini)

The idea of finding a new partner is strange for Eini, who has been alone for 15 years, although she has had friends who have re-partnered in old age after bereavement. Even though it has become increasingly common for older people to build new relationships after a divorce or the loss of a partner, for Eini, a new intimate relationship, even living-apart-together (LAT) (Duncan and Philips 2010; Jong Gierveld 2004; Karlsson and Borell 2005), is not an option. According to the GOAL study results, in Eini's age cohort, born 1926-1930, less than 4 per cent of those who are divorced, unmarried or widowed are currently in a new relationship but living apart. In younger age cohorts, born 1946-1950, up to one-quarter $(20-29 \%)$ are in a LAT relationship (Karisto, Koskimäki and Seppänen $2013)$.

\section{Absence of meaningful friendship}

Friendships are known to have an emotional and social function (Samter 2003; Virtanen 2015), which was apparent also in our data. Yet, in this section, we focus on the aspect of emotional support given, or in the case of loneliness longed for, from a friendship.

After Eini's husband passed away, friends took on an important role in her everyday life. She enjoyed inviting friends over, but after undergoing surgery a year before the interview, she had to lie down a lot and could 
not even pour a cup of coffee for a friend. Eventually, she felt better, but no one visited. Eini believes that her poor health frightens people. Now that leaving home is difficult, friends would be most needed. Eini also misses the friends she has lost. They were women living in the neighbourhood, with whom Eini could sit on the bench outside and just talk for hours. Now she feels that she is the only one left.

Older adults are known to value relationships with friends their own age, and meaningful social contacts are an important part of wellbeing (Holmén and Furukawa 2002; Victor, Scambler and Bond 2009). In addition to wellbeing, loneliness is most often associated not with the number of contacts with friends and family, but with the quality of these relationships; that is, the expectations from and satisfaction with the contacts (Litwin and Shiovitz-Ezra 20o6; Routasalo et al. 2006). Hence, the longing for a friend is not always explained by losses and therefore by the decrease of network size, which, for many, is inevitable in old age. One might have friends and acquaintances, but the relationships are not always the kind that one hopes for. Lauri, introduced earlier, describes another unfulfilled relationship. He has an old friend whom he has known for years. They used to go fishing and dancing together, but after his friend got married and moved farther away to the countryside, the relationship changed.

It bothers me a little bit that even though we have known [each other] for many years, he never invites me to his place. He has a car and everything, so he could give me a lift. Warm up the sauna and spend the evening just talking. But he's not that kind of a friend. He comes by my place, but I can't go there. (Lauri)

For Lauri, the friendship he describes is important, but it does not live up to his expectations. Lauri feels that the relationship exists on his friend's terms and lacks reciprocity, which he considers an important part of friendship. The fact that his friend has not invited him over after settling down with his new partner makes Lauri feel unwanted and no more a part of his friend's life. Similar findings have been made among single, middle-aged men (Virtanen 2015) and unfulfilled expectations from contacts with friends have been discovered as one of the most powerful independent associations with loneliness (Savikko 2008).

In a longitudinal study, Johnson and Troll (1994) tracked the friendship patterns of older people who were 85 years old and over, and found that the expressive and affective dimensions of friendship were minimised. The older people appreciated the companionship and laughter that friendship provided, but friends did not necessarily function as confidants. Samter (2003) suggested that individuals in the latter stages of old age appear to define friendship in distinctly different ways. Friendship is no longer rooted in intimacy and support, and the boundaries of who might qualify 
as a friend are expanded. In older age, 'talk for talk's sake' may increase (Samter 2003).

Nonetheless, the emotional aspect of friendship appears essential; talking for talk's sake is not enough to fill the void of the lack of a meaningful relationship behind the loneliness. In particular, the men interviewed described a need for warm friendship, as Aatos, expresses it:

Mostly I miss warm friendship. Someone you can talk to about everything. A really good friend. (Aatos)

Olavi is married, but his wife has been at a nursing home for several years. Days often go by when Olavi sits around in coffee shops, where he usually finds someone to chat with. But most of all, he misses a friend with whom he could travel and see the world. Finding the right kind of friend is not easy, but Olavi has not given up hope:

I don't really have a friend I could visit or who could come by my place. I haven't found one, although I've tried. You're just not at the same wavelength with everyone. But you just have to stay optimistic about it. (Olavi)

The other men interviewed are not as optimistic about finding meaningful friendships. Aatos, introduced earlier, divorced in the 1970s. Now he lives alone in the centre of a small town. His daughter lives nearby, but they rarely see each other. Sore legs have started to bother Aatos, and especially in the wintertime, walking has become difficult. Aatos has a lot of acquaintances in the neighbourhood where he has lived almost all his life, but he is not that keen on befriending everyone:

There are not many whom you like being with. There are some people whom you can't get rid of when you meet them outside. They just talk and talk and don't stop. (laughs) (Aatos)

Vilho lives alone in a small town that he moved to from the countryside nine years ago. He has poor hearing and does not go out much, but his next-door neighbour has kept him busy, although not always in a good way:

He comes by almost every day. He buys a little bottle of liquor and just babbles. I don't really like it that much. (Vilho)

Samter (2003) pointed out that even though the criteria for defining friends become more liberal in old age, the willingness to tolerate a difficult companion decreases, as reflected in both Vilho's and Aatos's experiences. Rather than being pleased with any kind of social interaction, they feel annoyed with meaningless relationships in which they have not found needed companions. For Vilho, social interactions are challenging because of his loss of hearing. Keeping up with other people's talk is difficult, especially if the other person does not articulate clearly and 'just babbles'. 
Because of his poor hearing for Vilho 'three is a crowd', but recently, that has not been a problem; times have changed, and people do not visit as they used to. Vilho also misses the days when neighbours were close, and everyone used to greet one another when walking on the sidewalks, which suggests that both emotional and social aspects are intertwined in his experience of loneliness.

\section{Complex parenthood}

Among the interviewees, both Heikki and Aatos lost children in accidents over 30 years ago. Heikki briefly brings up the loss of his son and said that his sister's grandchildren visited him occasionally. He feels blessed that he has kin, but since his wife's death, Heikki has started to wonder what would happen to the house when he was gone. He believes it will be demolished because there is no one to whom he could leave it.

I'm not jealous of my own family [sisters], but honestly, I think some people don't understand how precious it is to have offspring. (Heikki)

An older person with no offspring often faces more losses than the absence of new relationships; not having children means not having grandchildren (Aartsen et al. 2004). Being a grandparent can be one of the most important roles in one's lifetime. It means not only belonging to a chain of generations, but also knowing that one's own life continues in others' lives (Arber and Timonen 2012). The lack of grandchildren can feel overwhelming, as it sometimes has for Anja. She has a son who is childless, which makes Anja sad. She believes that life would have more meaning with grandchildren in it.

Anneli has never been married and has no children. She mentions her childlessness when recalling the times she felt most lonely. Anneli describes the previous Sunday, which happened to be Easter, when children were running around the neighbourhood:

My neighbours have kids and grandkids coming by, but I don't have anyone who would stop by like that. (Anneli)

Although seeing other people with families makes Anneli feel lonely, she adds that it still would not be nice to have them visiting all the time. Anneli has heard that children and grandchildren have become a burden to some of her friends. Karisto, Koskimäki and Seppänen (2013) have found that up to 13 per cent of women aged 62-66 years say that grandchildren do not bring joy to life; ten years earlier, only 2 per cent thought so. In older age groups, this trend was not found, which might indicate the changing expectations from social contacts with children and grandchildren. 
Not having children may be a cause of loneliness, but being a parent does not always protect one from being lonely (Linneman and Leene 1990; Zhang and Hayward 2001). Children are also an important source of worries and parents often incur pain from what happens to their children or from what children do (Dykstra and Hagestad 2007). As in friendship, in parenthood one may have unfulfilled hopes of a different kind of relationship with children and grandchildren. Helmi wishes that her son and grandchildren would keep in touch with her more often. Helmi's son lives nearby with his family, but their hectic lifestyle has made Helmi feel that they have no time for her:

I called them today; they're both working. And all the time renovating their place. They bought an old house. I haven't been there for ages. They never invite me. Maybe they're always working. (Helmi)

Helmi emphasises that she is not angry or bitter, because her son and daughter-in-law help with household chores and other practical things when they have the time. However, Helmi spends holidays, such as Christmas, alone. The practical support Helmi has been given has been insufficient to fulfil her expectations of the relationships; most of all, she misses spending time with her son and grandchildren and feeling a part of their family. Savikko (2008) also argues that loneliness is associated with expectations from, and satisfaction with, one's contacts and not so much with the frequency of contacts or the number of significant others (also e.g. Mullins and Dugan 1990).

Pauli lives in the city with his wife. He has three children, but he does not see them that much. They all live an hour's drive from Pauli, but according to him they are unable to visit due to lack of time and money. He is on good terms with his children but feels that something is missing. For Pauli, the relationship with his sons-in-law, particularly, seem troubling.

I speak on the phone with my oldest [son] almost every day, but not with the others. I didn't really get good sons-in-law. They don't have time for this old man. (laughs) Haven't asked me to go fishing with them. (Pauli)

Pauli talks about things he would like to do with his son and sons-in-law, such as fishing. He has a summer cottage, but no one seems to have time to help with its maintenance. For Pauli, these unfulfilled expectations come to mind when talking about loneliness, yet he finds the cause of loneliness way back from his childhood.

\section{Troubling childhood experiences}

The loss of a parent and a childhood home can be difficult to overcome, even in adulthood, when one has one's own children (Krause 1993; 
Palkeinen 2005). For generations who lost their parents during the war, this can be a common experience. Pauli describes the loss of his mother, which has had an effect not only on his expectations for his own parenthood, but also on his self-confidence. As a child, Pauli felt like an outsider. His father remarried, and Pauli had to spend several summers working in the countryside far away from home.

I was lonely even as a little kid. It didn't feel like home. I spent five long summers there, and every time I came back home, I didn't have any friends because I had been gone for so long. And at school, there was this boy who had the same name as mine, and the teacher started calling me by my second name, which I didn't like at all. My name was Pauli, but the teacher called me Sakari. And at the summer place, I was called little Pauli because there was also another boy called Pauli. So I had three names. (Pauli)

Sarvimäki, Stenbock-Hult and Heimonen (2010) describe 'a vulnerability of the mind' that, in old age, is connected to one's lifecourse: the outcomes of previous life events shape the way the present and the future are met, sometimes with high hopes and sometimes with fears. This can also be recognised in Pauli's experience of loneliness, which he has been unable to shake off despite having a life companion and children of his own. Pauli believes that the fear of being left alone was still present because of the loss of his mother, and it has been a burden on his relationships.

The significance of childhood experiences for later experiences of loneliness have been discussed, referring, for example, to John Bowlby's (1971) ideas of the relationship between loneliness and problems in early attachment. Childhood socio-economic adversity, poor health and parental substance abuse are known to be detrimental to self-esteem and self-efficacy, which give rise to feelings of powerlessness, rejection and self-perceived lack of disclosure to others (Jong Gierveld 1998) and may have longlasting effects on loneliness, directly or indirectly (Hawkley and Cacioppo 2007; Hensley et al. 2012; Kamiya et al. 2014). However, some empirical findings do not support the causal relationship between childhood circumstances (Savikko 2008), referring to the possibility of compensating for parental loss with other adult relationships.

Among the interviewees, Aatos and Anneli also briefly reviewed their childhood. Similar to Pauli, Aatos lost his mother when he was young. His father remarried, but he felt that he never got the affection he needed from his stepmother. Aatos says he felt abandoned and an outsider in his childhood home. Anneli - ten years younger than Aatos - recalls her insecurity in early childhood. Finland was at war, and Anneli's mother struggled with taking care of small children and household chores on her own. She fell into severe depression, and Anneli remembers taking responsibility for her younger siblings at a very young age. Even though Anneli's 
mother recovered from depression, and they had a good relationship until her mother passed away, Anneli feels that her mother's depression has followed her throughout her life.

Ottmann and Maragoudaki (2015) suggest that researchers have largely ignored how unresolved traumatic events experienced earlier in life can have an impact on resilience later in life although war-related and other significant traumatic events are a common occurrence in older population. Adversities and traumatic events experienced earlier in life may have a lasting impact on a person or family, which potentially reduces older people's capabilities when facing future challenges.

\section{Conclusion}

In this article, we have examined emotional loneliness in old age and the past and present experiences behind it. Interviews with ten older adults who reported feeling lonely often or all the time have drawn a picture of the multifaceted nature of loneliness and its causes. The meaning of lost relationships and the quiet longing for fulfilling ones were manifested as powerful factors behind emotional loneliness in old age. Due to the increase of their disabilities and the decrease of their social integration, the older people referred to loneliness as an inevitable part of ageing, but the cause of loneliness was equivocal.

Some of the interviewees have lost a companion or a child, or a parent in their own childhood. Meaningful relationships have ended, and expectations towards social engagement have not been fulfilled. These older people seek for a new partner or a good friend, or miss the company and emotional support of children and grandchildren. Friends and family members have passed away, and new relationships have not been found due to increased disabilities or sometimes just not being on the 'same wavelength'.

Our findings have emphasised the importance of the quality (not the quantity) of relationships from a complimentary approach: adding to the understanding of how emotional loneliness develops within older people. Generally, our findings reflect loneliness experienced in a individualistic society, in which the characteristics of loneliness are more often linked to the absence of a confidant or friends than interactions with family as in the more collectivistic societies (Lykes and Kemmelmeier 2013). However, also lost or unfulfilling familial social bonds were described as causes for loneliness by our interviewees. Above all, loneliness was reflected as a personal experience embedded in previous life events and the present everyday life surrounding these older people. 
Effective alleviation of loneliness requires an in-depth understanding about the quality and diversity of the experiences of loneliness and the considerable differences in the way older people handle their life situations. Many of our interviewees have faced loneliness that only began in old age, but for some, loneliness has been present for nearly a lifetime because of, for example, loss of a parent in childhood. In future research concerning loneliness in old age it would be useful to examine loneliness from a lifecourse perspective (e.g. Dannefer and Settersten 2010), in order to grasp the dynamic nature of loneliness and explore how the experiences of loneliness are embedded not only in different life histories of older people, but also the wider social context surrounding loneliness in old age.

\section{Acknowledgements}

We thank our fellow researchers who have worked on the GOAL research project at Palmenia, University of Helsinki. The GOAL research project has been funded by the European Union and Päijät-Häme Hospital District.

\section{References}

Aartsen, M. and Jylhä, M. 2011 . Onset of loneliness in older adults: results of a 28year prospective study. European Journal of Ageing, 8, 1, 31-8.

Aartsen, M., Van Tilburg, T., Smits, C. and Knipscheer, K. 2004. A longitudinal study of the impact of physical and cognitive decline of the personal network in old age. Journal of Social and Personal Relationships, 21, 2, 249-66.

Andersson, L. 1998. Loneliness research and interventions: a review of the literature. Aging $\mathcal{E}^{2}$ Mental Health, 2, 4, 264-74.

Arber, S. and Timonen, V. (eds) 201 2. Contemporary Grandparenting: Changing Family Relationships in Global Contexts. Policy Press, Bristol, UK.

Baarsen, B., Snijders, T., Smit, J. and van Duijn, M. 2001. Lonely but not alone: emotional and social isolation as two distinct dimensions of loneliness in older people. Educational and Psychological Measurement, 61, 1, 119-35.

Berg, S., Mellström, D., Persson, G., and Svanborg, A. 1981. Loneliness in the Swedish aged. Journal of Gerontology, 36, 3, 342-9.

Bowlby, J. 1971. Attachment and Loss. Volume 1, Attachment. Penguin Books, Harmondsworth, UK.

Cacioppo, J. T., Hawkley, L. C. and Thisted, R. A. 2010. Perceived social isolation makes me sad: 5-year cross-lagged analyses of loneliness and depressive symptomatology in the Chicago Health, Aging, and Social Relations Study. Psychology and Aging, 25, 2, 453 .

Cacioppo, J. T. and Patrick, W. 2008. Loneliness: Human Nature and the Need for Social Connection. W.W. Norton \& Company, New York.

Dahlberg, K. 2010. The enigmatic phenomenon of loneliness. International Journal of Qualitative Studies on Health and Well-being, 2, 4, 195-207.

Dahlberg, L. and McKee, K. J. 2013. Correlates of social and emotional loneliness in older people: evidence from an English community study. Aging and Mental Health, 18, $4,5^{\mathrm{O}} 4^{-14}$. 
Dannefer, D. and Settersten, R. 2010. The study of the life course: implications for social gerontology. In Dannefer, D. and Phillipson, C. (eds), The Sage Handbook of Social Gerontology. Sage, London, 3-20.

Drageset, J. 2004. The importance of activities of daily living and social contact for loneliness: a survey among residents in nursing homes. Scandinavian Journal of Caring Sciences, 18, 1, 65-71.

Drennan, J., Treacy, M., Butler, M., Byrne, A., Fealy, G., Frazer, K. and Irwing, K. 2008. The experience of social and emotional loneliness among older people in Ireland. Ageing E Society, 28, 8, $1113^{-32}$.

Duncan, S. and Phillips, M. 2010. People who live apart together (LATs) - how different are they? The Sociological Review, 58, 1, $112-34$.

Dykstra, P.A. and Fokkema, T. 2007. Social and emotional loneliness among divorced and married men and women: comparing the deficit and cognitive perspectives. Basic and Applied Social Psychology, 29, 1, 1-12.

Dykstra, P. A. and Hagestad, G. O. 2007. Roads less taken: developing a nuanced view of older adults without children. Journal of Family Issues, 28, $10,1275^{-1} 310$.

Dykstra, P. A. and Jong Gierveld, J. 2004. Gender and marital-history differences in emotional and social loneliness among Dutch older adults. Canadian Journal on Aging/La revue canadienne du vieillissement, 23, 2, 141-55.

Fees, B., Martin, P. and Poon, L. 1999. A model of loneliness in older adults. Journal of Gerontology, 54B, 4, 231-9.

Geller, J., Janson, P., McGovern, E. and Valdini, A. 1999. Loneliness as a predictor of hospital emergency department use. Journal of Family Practice, 48, 10, 801-4.

Graneheim, U. H. and Lundman, B. 2010. Experiences of loneliness among the very old: the Umeå 85 + Project. Aging and Mental Health, 14, 4, 433-8.

Gunnarsson, E. 2009. 'I think I have had a good life': the everyday lives of older women and men from a life-course perspective. Ageing $\mathcal{E}$ Society, 29, 1, 33-48.

Hawkley, L. and Cacioppo, J. 2007. Aging and loneliness. Downhill quickly? Current Directions in Psychological Science, 16, 4, 187-91.

Hensley, B., Martin, P., Margrett, J. A., MacDonald, M., Siegler, I. C., Poon, L. W. and The Georgia Centenarian Study 1. 2012. Life events and personality predicting loneliness among centenarians: findings from the Georgia Centenarian Study. Journal of Psychology, 146, 1/2, 1 73-88.

Heravi-Karimooi, M., Anoosheh, M., Foroughan, M., Sheykhi, M. T. and Hajizadeh, E. 2010. Understanding loneliness in the lived experiences of Iranian elders. Scandinavian Journal of Caring Sciences, 24, 2, 274-80.

Holmén, K., Ericsson, K., Andersson, L. and Windblad, B. 1992. Loneliness among elderly people living in Stockholm: a population study. Journal of Advanced Nursing, $17,1,43^{-} 5^{1}$.

Holmén, K. and Furukawa, H. 2002. Loneliness, health and social network among elderly people - a follow-up study. Archives of Gerontology and Geriatrics, 35, 3, 261-74.

Johnson, C. and Troll, L. 1994. Constraints and facilitators to friendships in late late life. The Gerontologist, 34, 1, 79-87.

Jong Gierveld, J. 1998. A review of loneliness: concept and definitions, determinants and consequences. Reviews in Clinical Gerontology, 8, 1, 73-80.

Jong Gierveld, J. 2004. Remarriage, unmarried cohabitation, living apart together: partner relationships following bereavement or divorce. Journal of Marriage and Family, 66, 1, 236-43.

Jylhä, M. 2004. Old age and loneliness: cross-sectional and longitudinal analyses in the Tampere Longitudinal Study on Aging. Canadian Journal on Aging, 23, 2, $157-68$. 
Jylhä, M. and Saarenheimo, M. 2010. Loneliness and aging: comparative perspectives. In Dannefer, D. and Phillipson, C. (eds), The Sage Handbook of Social Gerontology. Sage, London, 21 7-328.

Kamiya, Y., Doyle, M., Henretta, J. C. and Timonen, V. 2014. Early-life circumstances and later-life loneliness in Ireland. The Gerontologist, 54, 5, 773-83.

Karisto, A., Koskimäki, T. and Seppänen, M. 2013. Sosiaaliset suhteet [Social relations]. In Haapola, I., Karisto, A. and Fogelholm, M. (eds), Vanhuusikä muutoksessa. Ikihyvä Päijät-Häme -tutkimuksen tuloksia 2002-2OI2 [The Changing Old Age. Results from GOAL Study 2002-2012]. Päijät-Hämeen sosiaali- ja terveysyhtymän julkaisuja, Päijät-Häme, Finland, 72.

Karlsson, S. G. and Borell, K. 2005. A home of their own. Women's boundary work in LAT-relationships. Journal of Aging Studies, 1 9, 1, 73-84.

Kirkevold, M., Moyle, W., Wilkinson, C., Meyer, J. and Hauge, S. 2013. Facing the challenge of adapting to a life 'alone' in old age: the influence of losses. Journal of Advanced Nursing, 69, 2, 394-403.

Kivett, V. R. 1979. Discriminators of loneliness among the rural elderly: implications for intervention. The Gerontologist, 19, 1, 108-15.

Krause, N. 1993. Early parental loss and personal control in later life. Journal of Gerontology, 48, 3, 11 7-26.

Layder, D. 1998. Sociological Practice: Linking Theory and Social Research. Sage, London.

Linneman, M. and Leene, G. 1990. Loneliness among the frail elderly and possibilities for intervention by primary care caregivers. Report of an inventory study in 2 Amsterdam neighborhoods. Tijdschrift voor Gerontologie en Geriatrie, 21 , $4,161-8$.

Litwin, H. and Shiovitz-Ezra, S. 2006. The association between activity and wellbeing in later life: what really matters? Ageing $\mathcal{E}$ Society, 26, 2, $225^{-42}$.

Liu, B. S. and Rook, K. S. 2013 . Emotional and social loneliness in later life: associations with positive versus negative social exchanges. Journal of Social and Personal Relationships, 3o, 6, 813-32.

Lopata, H. Z. 1969. Loneliness: forms and components. Social Problems, 17, 2, $248-$ 62.

Luo, Y., Hawkley, L. C., Waite, L. J. and Cacioppo, J. T. 201 2. Loneliness, health, and mortality in old age: a national longitudinal study. Social Science $\mathcal{E}^{2}$ Medicine, 74, 6, 907-14.

Lykes, V.A. and Kemmelmeier, M. 2013. What predicts loneliness? Cultural difference between individualistic and collectivistic societies in Europe. Journal of Cross-cultural Psychology, 45, 3, 468-9o.

Marangoni, C. and Ickes, W. 1989 . Loneliness: a theoretical review with implications for measurement. Journal of Social and Personal Relationships, 6, 1, 93-128.

McInnis, G. and White, J. 2001. A phenomenological exploration of loneliness in the older adult. Archives of Psychiatric Nursing, 15, 3, $128-39$.

Molloy, G.J., McGee, H. M., O’Neill, D. and Conroy, R. M. 2010. Loneliness and emergency and planned hospitalizations in a community sample of older adults. Journal of the American Geriatrics Society, 58, 8, $153^{8-41 .}$

Mullins, L. C. and Dugan, E. 1990. The influence of depression, and family and friendship relations, on residents' loneliness in congregate housing. The Gerontologist, 3o, 3, 377-84.

Ottmann, G. and Maragoudaki, M. 2015 . Fostering resilience later in life: a narrative approach involving people facing disabling circumstances, carers and members of minority groups. Ageing $\mathcal{E}^{2}$ Society, 35, 10, 2071-99.

Palkeinen, H. 2005. Yksinäisyys iäkkäiden ihmisten kirjoituksissa [Loneliness in older people's writings]. Gerontologia, 19, 3, $1111-20$. 
Rokach, A. 2004. Loneliness then and now: reflections on social and emotional alienation in everyday life. Current Psychology, 23, 1, 24-40.

Routasalo, P., Savikko, N., Tilvis, R., Strandberg, T. and Pitkälä, K. 20o6. Social contacts and their relationship to loneliness among aged people: a population-based study. Gerontology, 52, 3, 181-7.

Russell, D., Cutrona, C., de la Mora, A. and Wallace, R. 1997. Loneliness and nursing home admission among rural older adults. Psychology and Ageing, 12, 4, 574-89.

Samter, W. 2003. Friendship interaction skills across the life span. In Greene, J. O. and Burleson, B. R. (eds), Handbook of Communication and Social Interaction Skills. Psychology Press, Mahwah, New Jersey, 637-84.

Samuelsson, G., Andersson, L. and Hagberg, B. 1998. Loneliness in relation to social, psychological and medical variables over a 13-year period: a study of the elderly in a Swedish rural district. Journal of Mental Health and Aging, 4, 3, 361-78.

Sarvimäki, A. Stenbock-Hult, B. and Heimonen, S. 2010. Ikääntyminen ja mielen haavoittuvuus - haavoittuvuus riskinä ja voimavarana [Aging and vulnerability of the mind as a risk and resource]. Gerontologia, 24, 2, 169-78.

Savikko, N. 2008. Loneliness of older people and elements of an intervention for its alleviation. Doctoral dissertation, Annales Universitatis Turkuensis, Serie D, 8o8, Turku, Finland.

Savikko, N., Routasalo, P., Tilvis, R., Strandberg, T. and Pitkala, K. 2005. Predictors and subjective causes of loneliness in an aged population. Archives of Geriatrics and Gerontology, 41, 3, 223-33.

Stanley, M., Moyle, W., Ballantyne, A., Jaworski, K., Corlis, M., Oxlade, D., Stoll, A. and Young, B. 2010. 'Nowadays you don't even see your neighbours': loneliness in the everyday lives of older Australians. Health and Social Care in the Community, $18,4,407-14$.

Steed, L., Boldy, D., Grenade, L. and Iredell, H. 2007. The demographics of loneliness among older people in Perth, Western Australia. Australasian Journal of Ageing, 26, 2, 81-6.

Tijhuis, M. A., Jong Gierveld, J., Feskens, E. J. and Kromhout, D. 1999. Changes in and factors related to loneliness in older men. The Zutphen Elderly Study. Age and Ageing, 28, 5, 491-5.

Uotila, H. 2011. Vanhuus ja yksinäisyys. Tutkimus iäkkäiden ihmisten yksinäisyyskokemuksista, niiden merkityksistä ja tulkinnoista [Old age and loneliness. A study of older people's experiences of loneliness and their meanings and interpretations]. Doctoral dissertation, Tampere University Press, Tampere, Finland.

Uotila, H., Lumme-Sandt, K. and Saarenheimo, M. 2010. Lonely older people as a problem in society - construction in Finnish media. International Journal of Ageing and Later Life, 5, 2, 103-30.

Victor, C., Scambler, S. and Bond, J. 2009. The Social World of Older People. Understanding Loneliness and Social Isolation in Later Life. McGraw-Hill International, Maidenhead, UK.

Victor, C., Scambler, S., Bowling, A. and Bond, J. 2005. The prevalence of, and risk factors for, loneliness in later life: a survey of older people in Great Britain. Ageing E Society, 25, 6, 357-75.

Victor, C. and Bowling, A. 2012. A longitudinal analysis of loneliness among older people in Great Britain. Journal of Psychology, 146, 3, 313-31.

Virtanen, I. 2015 . Supportive communication in Finnish men's friendships. Doctoral dissertation, Tampere University Press, Tampere, Finland.

Weiss, R. 1973. Loneliness: The Experience of Emotional and Social Isolation. MIT Press, Cambridge, Massachusetts. 
1088 Elisa Tiilikainen and Marjaana Seppänen

Wenger, C. and Burholt, V. 2004. Changes in levels of social isolation and loneliness among older people in a rural area: a twenty-year longitudinal study. Canadian Journal on Aging, 23, 2, $115^{-27}$.

Wenger, C., Davies, R., Shahtahmasebi, S. and Scott, A. 1996. Social isolation and loneliness in old age: review and model refinement. Ageing $\mathcal{E} \sigma$ Society, 16, 3, $333^{-} 5^{8 .}$

Yang, K. and Victor, C. 2011 . Age and loneliness in 25 European nations. Ageing $\mathcal{E}^{2}$ Society, 31, 8, 1368-88.

Zhang, Z. and Hayward, M. 2001. Childlessness and the psychological well-being of older persons. Journals of Gerontology: Social Sciences, 56, 5, 311-20.

Accepted 7 January 20I6; first published online 5 February 2016

Address for correspondence:

Elisa Tiilikainen,

Department of Social Sciences,

University of Eastern Finland,

PO Box 1627 ,

70211 Kuopio, Finland

E-mail: elisa.tiilikainen@uef.fi 